\title{
PENURUNAN DERAJAT AKNE VULGARIS SETELAH PENGGUNAAN KOMBINASI KRIM ANTI AKNE DI JAKARTA BARAT
}

\author{
Jessica Elizabeth ${ }^{1}$, Sukmawati Tansil Tan², Michelle Angelika ${ }^{3}$, Yohanes Firmansyah ${ }^{4}$, \\ Yana Sylvana ${ }^{5}$, Novendy ${ }^{6}$
}

\author{
1, 2, 3, 4, 5 Departemen Ilmu Penyakit Kulit dan Kelamin, Universitas Tarumanagara Jakarta \\ Email: je.chika19@gmail.com \\ ${ }^{6}$ Departemen Ilmu Kesehatan Masyarakat, Universitas Tarumanagara Jakarta \\ Email: novendy@fk.untar.ac.id
}

Masuk: 23-12-2019, revisi: 11-05-2020, diterima untuk diterbitkan: 12-05-2020

\begin{abstract}
ABSTRAK
Akne vulgaris adalah inflamasi atau peradangan setempat pada kelenjar pilosebasea. Menurut Studi Dermatologi Kosmetika Indonesia, pada tahun 2006-2009 terdapat peningkatan prevalensi akne vulgaris. Remaja wanita usia 14-17 tahun memiliki prevalensi sebesar 83-85\%, sedangkan pria usia 16-19 tahun sebesar 95-100\%. Akne vulgaris mempunyai dampak yang cukup besar bagi para penderita remaja secara fisik dan psikologik. Ketepatan dalam terapi akne vulgaris merupakan langkah yang penting karena berpengaruh pada kesembuhan dan prognosis pasien. Obat topikal kombinasi krim anti akne yang mengandung retinoid, antibiotik dan kortikosteroid merupakan salah satu pilihan terbaik karena semua komponen yang dibutuhkan untuk mengatasi akne dapat digabung menjadi satu. Tujuan penelitian ini adalah untuk mengetahui proporsi penderita akne vulgaris pada remaja usia 14-19 tahun dengan derajat akne ringan, sedang dan berat sebelum dan sesudah diberikan intervensi, mengetahui hubungan pemberian intervensi dengan penurunan derajat akne vulgaris dan mengetahui proporsi penderita akne vulgaris pada remaja yang diberikan intervensi dan mengalami penurunan derajat akne vulgaris. Metodologi penelitian adalah uji klinik dengan desain penelitian eksperimental. Penelitian dilakukan di SMKN 35 Jakarta Barat pada periode September - November 2019 dengan teknik non-random consecutive sampling. Intervensi yang diberikan adalah kombinasi krim anti akne yang mengandung Klindamisin 3\%, Tretinoin $0.05 \%$, dan Deksametason $0.05 \%$. Analisis asosiasi statistik menggunakan uji statistik Wilcoxon untuk mengukur perbedaan derajat akne vulgaris sebelum dan sesudah intervensi. Hasil penelitian didapatkan didapatkan perbaikan derajat akne vulgaris yang bermakna ( $p$-value < $0,001)$ antar pengukuran akibat pemberian intervensi. Dapat disimpulkan bahwa kombinasi krim anti akne dengan kandungan Klindamisin 3\%, Tretinoin 0.05\%, dan Deksametason 0.05\%. dapat menurunkan derajat keparahan akne vulgaris secara bermakna.
\end{abstract}

Kata Kunci: Akne vulgaris; Deksametason; Tretinoin; Klindamisin;

\begin{abstract}
Acne vulgaris is a local inflammation of the pilosebaceous glands. According to Indonesian Cosmetics Dermatology Study, there was an increase in the prevalence of acne vulgaris in 2006-2009. Female adolescents aged 14-17 years have a prevalence of $83-85 \%$, while male adolescents aged 16-19 years have 95-100\% prevalence. Acne vulgaris has a significant impact on adolescents, physically and psychologically. Accuracy in the treatment of acne vulgaris is an important step because it affects patient's prognosis. Topical combination of anti-acne creams cointaining retinoid, antibiotics and corticosteroids is one of the best choices because all the components needed to treat acne can be combined. The purpose of this study is to determine the proportion of adolescents aged 14-19 years who suffer acne vulgaris with mild, moderate, and severe degrees before and after the intervention was given, to determine if the intervention given is related to decreasing of acne vulgaris severity, and to determine the proportion of adolescent patients with acne vulgaris which have been given intervention and experiencing a decrease in acne vulgaris severity. This is a clinical trial with an experimental research design. The study was conducted at SMKN 35 West Jakarta in September-November 2019 with non-random consecutive sampling techniques. The intervention given were a combination of anti-acne creams containing Clindamycin 3\%, Tretinoin 0.05\%, and Dexamethasone 0.05\%. Wilcoxon statistical test is used to measure differences in severity of acne
\end{abstract}


vulgaris before and after the intervention. The results obtained showed significant decrease in acne vulgaris severity ( $p$-value <0.001) between measurements due to the intervention. It can be concluded that the combination of antiacne creams containing Clindamycin 3\%, Tretinoin 0.05\%, and Dexamethasone 0.05\% can significantly decrease the severity of acne vulgaris.

\section{Keywords: Acne vulgaris; Tretinoin; Clindamycin; Dexamethasone}

\section{PENDAHULUAN Latar Belakang}

Akne vulgaris adalah penyakit kronik umum yang terjadi pada kulit, yang melibatkan inflamasi atau peradangan setempat pada kelenjar pilosebasea (Rao, 2019). Sebagian besar kasus akne vulgaris muncul dengan susunan lesi pleomorfik yang terdiri dari komedo, papul, pustul, dan nodul dengan derajat keparahan yang bervariasi. Timbulnya akne pada wanita umumnya lebih awal dari pada pria karena efek pubertas dan hormon (Azarchi, et al., 2019). Prevalensi akne pada wanita ras Afrika Amerika dan Hispanik sebesar 37\% dan 32\%, pada ras Asia sebesar 30\%, pada ras Kaukasia sebesar 24\%, dan pada ras India sebesar 23\% (Perkins, et al., 2011). Remaja memiliki prevalensi yang cukup tinggi dengan angka 47-90\%. Berdasarkan data dari Studi Dermatologi Kosmetika Indonesia, pada tahun 2006 terdapat 60\% penderita akne, tahun 2007 terdapat $80 \%$ penderita akne, tahun 2009 terdapat $90 \%$ penderita akne. Hal tersebut membuktikan bahwa terdapat peningkatan prevalensi akne vulgaris dari tahun ke tahun (Purwaningdyah \& Jusuf, 2013). Remaja wanita usia 14-17 tahun memiliki prevalensi sebesar 83-85\%, sedangkan pada pria usia 16-19 tahun sebesar 95-100\% (Zaenglein, et al., 2012).

Terdapat empat faktor yang mempengaruhi terbentuknya akne yaitu; hiperproliferasi epidermis folikular sehingga terjadi sumbatan folikel, produksi sebum yang berlebihan, inflamasi, dan aktivitas Propionibacterium acnes (P. acnes) (Cong, et al., 2019). Akne vulgaris merupakan penyakit multifaktorial, antara lain faktor genetik, suku bangsa, ras, makanan, iklim, lingkungan, jenis kulit, kebersihan, penggunaan kosmetik, stres psikis, infeksi dan pekerjaan (Ghodsi, et al., 2009). Daerah predileksi berupa wajah, bahu, ekstremitas superior bagian atas, dada, dan punggung. Akne vulgaris bukan merupakan penyakit yang berbahaya, namun mempunyai dampak yang cukup besar bagi para penderita, terutama remaja secara fisik dan psikologik dapat menimbulkan kecemasan, depresi, dan mengurangi rasa percaya diri penderitanya (Murat, et al., 2018).

Ketepatan dan kecepatan dalam terapi akne vulgaris merupakan langkah yang penting karena dapat berpengaruh pada kesembuhan dan prognosis pasien (Afriyanti, 2015). Tatalaksana akne terbaik meliputi membatasi pertumbuhan bakteri yang dapat diatasi dengan penggunaan antibiotik, mengurangi inflamasi dengan obat-obatan golongan kortikosteroid, dan menghambat pembentukan mikrokomedo dengan retinoid (Sanjay, 2011). Penggunaan obat topikal berupa kombinasi krim anti akne merupakan salah satu pilihan terbaik karena semua komponen yang dibutuhkan untuk mengatasi akne dapat digabung menjadi satu. Selain itu, kombinasi krim anti akne menjadi pilihan peneliti karena biaya yang cukup murah, tidak invasif dan mudah diaplikasikan ke pasien dengan efek samping yang lebih sedikit dibandingkan dengan terapi lainnya (Zeichner, 2012).

\section{Rumusan Masalah}

Masalah yang menjadi fokus penelitian ini adalah tingginya angka kejadian akne vulgaris pada remaja usia 14-19 tahun sehingga dibutuhkan terapi yang lebih efektif dan efisien. Peneliti juga ingin mengetahui berapa proporsi penderita akne vulgaris pada remaja usia 14-19 tahun dengan derajat akne sedang dan berat sebelum dilakukan intervensi dan proporsi penderita akne vulgaris 
pada remaja usia 14-19 tahun dengan derajat akne ringan, sedang dan berat setelah dilakukan intervensi, hubungan pemberian intervensi dengan penurunan derajat akne akne vulgaris, dan berapa proporsi penderita akne vulgaris pada remaja usia 14-19 tahun yang mendapat intervensi dan mengalami penurunan derajat akne akne vulgaris.

\section{METODE PENELITIAN}

Penelitian ini merupakan penelitian uji klinik dengan desain penelitian eksperimental. Penelitian dilakukan di SMK Negeri 35 Jakarta Barat pada kurun waktu September- November 2019. Sampel penelitian ini adalah seluruh kelompok remaja berusia 14-19 tahun di SMK Negeri 35 Jakarta Barat pada periode September- Oktober 2019 yang memenuhi kriteria inklusi. Total responden dalam penelitian ini berjumlah 186 responden dengan teknik pengambilan sampel dengan cara non-random consecutive sampling/ total sampling. Kriteria inklusi berupa usia 1419 tahun, menderita akne vulgaris di area wajah tanpa memandang jenis kulit, menyetujui informed consent, dan Bersedia menggunakan kombinasi krim anti akne saja dan menghentikan semua perawatan kulit lainnya pada wajah minimal 3 hari. Kriteria eksklusi berupa responden dengan penyakit kulit lain pada wajah seperti dermatitis atopi, kontak, rosasea, infeksi virus, impetigo, infeksi jamur, erupsi akneformis dan responden yang dicurigai mempunyai alergi terhadap zat aktif yang terkandung dalam kombinasi krim anti akne. Intervensi yang diberikan berupa kombinasi krim anti akne dengan kandungan bahan aktif Klindamisin 3\%, Tretinoin $0.05 \%$, dan Deksametason $0.05 \%$.

Setelah responden bersedia untuk mengikuti penelitian ini, orang tua atau wali dari responden diminta untuk menandatangani formulir informed consent. Remaja yang bersedia menjadi responden penelitian mengisi kuisioner yang berisikan data diri dan informasi lain yang dibutuhkan. Langkah selanjutnya berupa pengambilan foto wajah responden dengan kamera DSLR lalu mengukur derajat akne vulgaris pada area wajah. Derajat akne vulgaris ditentukan berdasarkan jumlah lesi yaitu derajat ringan dengan jumlah komedo $<20$ atau lesi inflamasi $<15$ atau total lesi $<30$, derajat sedang dengan jumlah komedo 20-100 atau lesi inflamasi 15-50 atau total lesi 30-125, dan derajat berat dengan dengan jumlah kista $>5$ atau komedo $<100$ atau lesi inflamasi $>50$ atau total lesi $>125$. Setelah data terkumpul, masing-masing responden diberikan kombinasi krim anti akne dan dilakukan edukasi mengenai cara pemakaian pada wajah setiap malam selama satu bulan. Pengukuran derajat akne vulgaris diukur setiap dua minggu hingga dua kali pengukuran. Analisis asosiasi statistik menggunakan uji statistik Wilcoxon untuk mengukur perbedaan derajat akne vulgaris sebelum dan sesudah intervensi.

\section{HASIL DAN PEMBAHASAN}

Penelitian penurunan derajat akne vulgaris setelah penggunaan kombinasi krim anti akne didapatkan total responden sebanyak 94 responden dari 109 responden. Selisih responden atau 15 responden lainnya tidak diikut sertakan dikarenakan tidak berada di lokasi pengambilan sampel saat evaluasi dan menolak untuk diambil data berupa foto wajah saat evaluasi. Penelitian berakhir dengan jumlah responden yang berhasil menyelesaikan penelitian sebanyak 94 responden. Derajat keparahan akne vulgaris pada minggu ke-0 didapatkan 29 (30,9\%) responden dengan akne vulgaris berat dan $65(69,1 \%)$ responden dengan akne vulgaris sedang. Derajat keparahan akne vulgaris pada minggu ke-4 setelah diberikan intervensi kombinasi krim anti akne didapatkan $2(2,1 \%)$ responden dengan akne vulgaris berat, $37(39,4 \%)$ responden dengan akne vulgaris sedang, dan $55(58,5 \%)$ responden dengan akne vulgaris ringan. 
Tabel 1. Distribusi Karakteristik Derajat Akne Vulgaris 94 Responden SMKN 35 Jakarta Barat

\begin{tabular}{lc}
\hline \multicolumn{1}{c}{ Variabel } & Jumlah (\%) \\
& $\mathbf{N}=\mathbf{9 4}$ \\
\hline Derajat Akne Minggu-0 & \\
Akne berat & $29(30,9)$ \\
Akne sedang & $65(69,1)$ \\
\hline Derajat Akne Minggu-4 & $2(2,1)$ \\
Akne berat & $37(39,4)$ \\
Akne sedang & $55(58,5)$ \\
Akne ringan & \\
\hline
\end{tabular}

Hasil penelitian ini sesuai dengan penelitian yang dilakukan oleh Tjekyan RM dengan judul Kejadian dan Faktor Resiko Akne Vulgaris pada tahun 2008, dimana didapatkan prevalensi akne vulgaris tertinggi yaitu pada remaja berusia 14-17 tahun, dimana pada wanita berkisar antara 8385\% dan pada pria berusia 16-19 tahun yang berkisar antara 95-100\% (Tjekyan, 2008). Hasil ini juga sesuai dengan penelitian yang dilakukan oleh Emeka Okoro, Adebola Ogunbiyi dan Adekunie George mengenai prevalensi dan pola dari akne vulgaris pada remaja, dimana prevalensi tertinggi akne vulgaris didapatkan pada usia remaja karena kadar hormon androgen dan produksi sebum yang lebih tinggi saat masa pubertas (Okoro, et al., 2016). Tingginya kadar androgen akan menstimulasi produksi sebum lebih banyak lagi sehingga merupakan faktor predisposisi tersumbatnya pori-pori dan terbentuknya komedo (Uysal, et al., 2017)

Perubahan derajat akne vulgaris dari 94 responden didapatkan 78 responden yang mengalami perbaikan derajat keparahan akne dan 16 responden tanpa perubahan derajat keparahan akne. Analisa uji statistik menggunakan Uji Statistik Wilcoxon didapatkan perbaikan derajat akne vulgaris yang bermakna $(p$-value $<0,001)$ antar pengukuran akibat pemberian intervensi berupa kombinasi krim anti akne.

Tabel 2. Distribusi Karakteristik Derajat Akne Vulgaris 94 Responden SMKN 35 Jakarta Barat

\begin{tabular}{|c|c|c|c|c|c|c|c|}
\hline \multirow{2}{*}{ Waktu } & \multirow{2}{*}{$\begin{array}{c}\text { Derajat } \\
\text { Akne } \\
\text { Vulgaris }\end{array}$} & \multicolumn{3}{|c|}{ Derajat Akne Vulgaris } & \multicolumn{3}{|c|}{ Perubahan derajat akne } \\
\hline & & Berat & Sedang & Ringan & Total & & p-value \\
\hline \multicolumn{8}{|c|}{ Minggu 0 vs Minggu 4} \\
\hline \multirow{3}{*}{$\begin{array}{l}\text { Minggu } 0 \\
\text { vs } \\
\text { Minggu } 4\end{array}$} & Berat & $\begin{array}{c}2 \\
(2,1 \%)\end{array}$ & $\begin{array}{c}23 \\
(24,5 \%)\end{array}$ & $\begin{array}{c}4 \\
(4,3 \%)\end{array}$ & $\begin{array}{c}29 \\
(30,9 \%)\end{array}$ & Per & \\
\hline & Sedang & $\begin{array}{c}0 \\
(0,0 \%)\end{array}$ & $\begin{array}{c}14 \\
(14,9 \%)\end{array}$ & $\begin{array}{c}51 \\
(54,3 \%)\end{array}$ & $\begin{array}{c}65 \\
(69,1 \%)\end{array}$ & Tanpa perubahan 16 responden & \\
\hline & Total & $\begin{array}{c}2 \\
(2,1 \%)\end{array}$ & $\begin{array}{c}37 \\
(39,4 \%)\end{array}$ & $\begin{array}{c}55 \\
(58,5 \%)\end{array}$ & $\begin{array}{c}94 \\
(100 \%)\end{array}$ & Perburukan 0 responden & $<0,001$ \\
\hline
\end{tabular}

Hal ini sesuai dengan penelitian yang dilakukan di India oleh Sarvajnamurthy et al dengan judul Synchronizing Pharmacotherapy in Acne with Review of Clinical Care. Penelitian ini memaparkan bahwa kombinasi Tretinoin dengan antimikroba terutama Klindamisin merupakan kombinasi esensial dan dapat dipertimbangkan sebagai terapi lini pertama untuk akne derajat sedang dan berat. Tretinoin yang berfungsi sebagai keratolitik akan membantu penetrasi 
antimikroba kedalam unit pilosebasea dimana bakteri $P$. acnes berkolonisasi sehingga akan meningkatkan efektivitas obat (Sacchidanand, et al., 2017). Menurut Ashley, William, Tushar dan Steven pada penelitian mengenai kombinasi retinoid dan antimikroba sebagai pengobatan topikal akne, tujuan utama dari terapi kombinasi adalah untuk menargetkan berbagai area patogenesis jerawat yang tidak dapat dicapai degan monoterapi. Gabungan Klindamisin dan Tretinoin telah dikembangkan untuk menargetkan berbagai area patogenesis jerawat. Tretinoin bertindak sebagai komedolitik dan antiinflamasi, sedangkan klindamisin bertindak sebagai antimikroba dan menurunkan jumlah $P$. acnes (Schmidt, 2011). Kombinasi kedua obat ini dapat mengurangi pembentukan komedo dan membantu proses penyembuhan lesi jerawat dan sudah terbukti secara signifikan lebih efektif mengurangi lesi akne dibandingkan dengan pengobatan monoterapi (Feneran, et al., 2011). Menurut Thiboutot et al, kombinasi Klindamisin dan Retinoid topikal juga terbukti dapat meningkatkan kecepatan penyembuhan lesi dan menurunkan angka resistensi antimikroba terhadap P. acnes (Thiboutot, et al., 2009).

Menurut penelitian oleh Rianyta, Purwantyastuti, Sri, dan Larisa, topikal kortikosteroid sering digunakan sebagai antiinflamasi dan dipercaya jika digunakan sebagai terapi kombinasi dengan Tretinoin, maka dapat mengurangi efek samping iritasi dari Tretinoin tanpa memperparah eksaserbasi akne vulgaris (Riyanyta, et al., 2019). Coman et al melakukan penelitian selama 4 minggu menggunakan kombinasi Tretinoin dan kortikosteroid topikal pada separuh sisi wajah yang dibandingkan dengan pelembab non-komedogenik sebagai kontrol pada separuh sisi wajah lainnya. Hasil penelitian didapatkan sebanyak $86 \%$ responden melaporkan hasil yang lebih baik pada separuh sisi wajah yang menggunakan kombinasi Tretinoin dan kortikosteroid topikal, juga tidak ditemukan adanya efek samping iritasi, hal ini diduga berasal dari efek anti inflamasi kortikosteroid (Coman, et al., 2017).

\section{KESIMPULAN DAN SARAN}

Berdasarkan hasil penelitian dan pembahasan diatas dapat disimpulkan bahwa didapatkan perbaikan derajat akne vulgaris yang bermakna ( $p$-value $<0,001)$ antar pengukuran setelah pemberian intervensi berupa kombinasi krim anti akne dengan kandungan bahan aktif Klindamisin 3\%, Tretinoin 0.05\%, dan Deksametason 0.05\%.

\section{Ucapan Terima Kasih (Acknowledgement)}

Ucapan terima kasih sebesar-besarnya kami ucapkan kepada Tarumanagara University Human Research Ethics Committee sebagai komite etik penelitian, PT. Sukma Skin Treatment sebagai pendana dan SMK Negeri 35 sebagai fasilitator. 


\section{REFERENSI}

Afriyanti, R., (2015). Akne Vulgaris pada Remaja. J Majority, Febuary, 4(4), pp. 102-109.

Azarchi, S. et al., (2019). Androgens in women: Hormone-modulating therapies for skin disease. J Am Acad Dermatol, June, 80(6), pp. 1509-1521.

Coman, G. et al., (2017). A randomized, split-face, controlled, double-blind, single-centre clinical study: transient addition of a topical corticosteroid to a topical retinoid in patients with acne to reduce initial irritation. British Journal of Dermatology, 177(2), pp. 567-569.

Cong, T. et al., (2019). From pathogenesis of acne vulgaris to anti-acne agents. Arch Dermatol Res, July, 311(5), pp. 337-349.

Feneran, A., Kaufman, W. \& Dabade, T., (2011). Retinoid plus antimicrobial combination treatments for acne. Clin Cosmet Investig Dermatol, July, Volume 4, pp. 72-92.

Ghodsi, S., Orawa, H. \& Zouboulis, C., (2009). Prevalence, severity, and severity risk factors of acne in high school pupils: a community-based study. J Invest Dermatol, September, 129(9), pp. 2136-41.

Murat, E., Incilay, K. \& Damla, E., (2018). Evaluation of Adolescents Diagnosed with Acne Vulgaris for Quality of Life and Psychosocial Challenges. Indian J Dermatol, Mar-Apr, 63(2), pp. 131-135.

Okoro, E., Ogunbiyi, A. \& George, A., (2016). Prevalence and Pattern of Acne Vulgaris among Adolescents in Ibadan, Nigeria. Journal of the Egyptian Women's Dermatologic Society, January, 13(1), pp. 7-12.

Perkins, A. et al., (2011). Comparison of the epidemiology of acne vulgaris among Caucasian, Asian, Continental Indian and African American women. J Eur Acad Dermatol Venereol, September, 25(9), pp. 1054-1060.

Purwaningdyah, R. \& Jusuf, N., (2013). Profil Penderita Akne Vulgaris pada Siswa-Siswi di SMA Shafiyyatul Amaliyyah Medan. E-Journal FK USU, 1(1), pp. 1-8.

Rao,

J.,

(2019).

Acne

Vulgaris.

[Online]

Available at: $\quad$ https://emedicine.medscape.com/article/1069804-overview\#a6 [Accessed August 2019].

Riyanyta, Purwantyastuti, Menaldi, S. \& Paramitha, L., (2019). Kortikosteroid Intralesi: Aspek Farmakologik dan Penggunaan Klinis di Bidang Dermatologi. Media Dermato Venereologica Indonesiana, 46(1), pp. 51-56.

Sacchidanand, S. et al., (2017). Synchronizing Pharmacotherapy in Acne with Review of Clinical Care. Indian Journal of Dermatology, Jul-Aug, 62(4), pp. 341-357.

Sanjay, R., (2011). ACNE VULGARIS TREATMENT : THE CURRENT SCENARIO. Indian J Dermatol, Jan-Feb, 56(1), pp. 7-13.

Schmidt, N., (2011). Clindamycin plus tretinoin gel: Treatment of acne patients with all six Fitzpatrick skin types. Journal of the American Academy of Dermatology, 64(2), p. AB5. 
Thiboutot, D. et al., (2009). New insights into the management of acne : An update from the Global Alliance to Improve Outcomes in Acne Group. J AM ACAD DERMATOL, 60(5), pp. S1-S150.

Tjekyan, R., (2008). Kejadian dan Faktir Resiko Akne Vulgaris. Jurnal Media Medika Indonesiana, 43(1), pp. 6-12.

Uysal, G. et al., (2017). Is acne a sign of androgen excess disorder or not?. Eur J Obstet Gynecol Reprod Biol, April, Volume 211, pp. 21-25.

Zaenglein, A., Graber, E. \& Thiboutot, D., (2012). Acne Vulgaris and Acneiform Eruptions. In: Fitzpatrick's Dermatology in General Medicine. s.1.:McGraw-Hill, pp. 933-949.

Zeichner, J., (2012). Optimizing topical combination therapy for the treatment of acne vulgaris. $J$ Drugs Dermatol, Mar, 11(3), pp. 313-7. 
